\title{
The Effect of Teaching Factory Implementation on The Competence and Readiness to Work of Students of the Catering Service Study Program at SMKN 2 Mojokerto
}

\author{
Tri Wahyuni Indah Permata* Luthfiyah Nurlaela, Rita Ismawati \& Tri Rijanto \\ Postgraduate of State University of Surabaya, Surabaya, 60213, Indonesia. \\ tri.19008@mhs.unesa.ac.id; luthfiyahnurlaela@unesa.ac.id; ritaismawati@unesa.ac.id; tririjanto@unesa.ac.id \\ *Corresponding Author: tri.19008@mhs.unesa.ac.id | Phone Number: +62881357800757
}

\begin{abstract}
This study aims to analyze the effect of implementing the teaching factory on readiness to work through the competence of students. This research was conducted at SMKN 2 Mojokerto. This research is an ex-post facto research. The population of this study were students of class XI and class XII of the catering service program at SMKN 2 Mojokerto, totaling 193 students. The research sampling technique was simple random sampling and calculated using the Slovin formula, so that the number of research samples was 130 students. The data analysis technique used path analysis. Research data collection uses a questionnaire instrument on the variables of teaching factory implementation and readiness to work, while for competence using tests and observation sheets. Before being distributed to research respondents, a validation test was first conducted on each research instrument. In line with the objectives, the results of the study show that: (1) the implementation of the teaching factory has a positive effect on the competence of students at SMKN 2 Mojokerto; (2) The implementation of the teaching factory has a positive effect on the readiness to work of the students at SMKN 2 Mojokerto; (3) The competence of students has a positive effect on the readiness to work of students at SMKN 2 Mojokerto; and (4) the implementation of the teaching factory has a positive effect on the readiness to work of students at SMKN 2 Mojokerto through the competence of students.
\end{abstract}

Keywords: implementation of teaching factory; competence; readiness to work; pastries production

\section{Introduction}

The existence of education aims to form and change people who are able to have competitiveness so that they become quality human resources, so that education is the main requirement for realizing it. This is evidenced in the 2019 World Economic Forum explaining that Indonesia's economic competitiveness has decreased from position 45 to rank 50 . The reason is the low level of education which is dominated by junior high school graduates, even elementary school. Not only that, the quality of education in Indonesia is also the main focus in creating the competitiveness of quality human resources (Cahyani, 2019). This fact is the main basis for the government to improve Indonesian education for the better.

Another problem related to education is that the unemployment rate in Indonesia fluctuates, even tends to increase, especially during the Covid 19 pandemic that hit Indonesia. The increase in unemployment as of March 2020 increased by 2.67 million, bringing the total unemployed workforce to 9.77 million of the total workforces of 138.2 million. Not only that, the main contributor to unemployment was dominated by vocational high school graduates by $13.55 \%$. (Ramli, 2020).The increase in the unemployment rate and the decrease in the quality of human resources indicate that the goals and functions of education in Indonesia have not been achieved optimally. Whereas the vision of national education is not limited to helping facilitate and develop human resources, but also to prepare quality and improve professionalism and accountability of educational institutions and empower the community. (Daulay, 2019).

Based on this, the phenomenon of the dominance of vocational high schools as the largest contributor to unemployment in Indonesia is something that really needs to be considered and resolved together. Therefore, vocational high schools must be able to adapt and compete to create graduates who can be relied upon and welcome the developments and changes of the times and the future. Weaknesses from the implementation of vocational education include, the implementation of vocational education is still not perfect because there is no maximum support in strategic policies to determine the direction and objectives of legal products so that many vocational high schools graduates have not been absorbed in the world of 
work; the curriculum set in vocational high schools is considered to be less comprehensive because it must be adapted to the times and the curriculum developed must be adaptive or not seem to change; the role of the community in welcoming vocational high schools graduates is still not optimal, especially for the industrial business; vocational high schools infrastructure that are still inadequate; and human resources owned by some vocational high schools are still not professional (Said, 2019).

One of the educational processes that are expected to be able to educate and create students who are competent, have knowledge and skills is to use the teaching factory. This learning at least pays attention to the 2013 national curriculum, the demand for graduate users, the available facilities and the time (Widiatna, 2019). Therefore, the teaching factory is a fundamental element in improving the quality of vocational high schools graduates and getting to know the industrial business well so as to be able to prepare as early as possible. This learning model is a choice and a breakthrough at this time because it is considered capable of creating competent and readiness to working vocational high schools graduates (Asriati, Sulistyarini, Ulfah, \& Purwaningsih, 2017). One of the vocational high schools that implements factory teaching is SMKN 2 Mojokerto. The teaching factory implementation activity program carried out was the production of pastries. The form of pastry production activities at SMKN 2 Mojokerto is one form of teaching through the teaching factory. Teaching factory learning applied in this school deserves to be explored in depth in this study. This is because this school is part of a model school pilot project in East Java. This cannot be separated from the level of professionalism of educators, adequate facilities and infrastructure, adaptive vocational or educational programs and collaboration between schools and industry, MSMEs or entrepreneurs in order to accommodate the competencies and skills of students..

The implementation of the teaching factory at SMKN 2 Mojokerto itself began in 2018 in collaboration with the Midas Cookies pastry business. The implementation process is carried out by combining business concepts with vocational education in accordance with expertise competencies relevant to the existing food and beverage industry. The process of producing pastries at SMKN 2 Mojokerto is carried out from Monday to Friday from 08.00 to 17.00 in the month of Ramadan. The process of implementing the teaching factory starting from the process of looking for orders, receiving orders, shopping for materials, the manufacturing process, until the orders are completed and given to consumers are carried out by students. Each student during the implementation of the pastry production activity program is also required to be able to sell 5 types of cakes. Pastries production scheduling is carried out based on attendance and not based on a scheduling system that is in accordance with business or industry standards. With the implementation of the teaching factory program for pastry production activities, it is hoped that the students of the Catering Service program at SMKN 2 Mojokerto have one of the competencies in one field, namely the production of pastries, so that in the future graduates of SMKN 2 Mojokerto can have better work experience and readiness to working in the field of pastry production and the like.

During the teaching factory for the pastry activity program, it was discovered that Midas Cookies, which supports the pastry production activity program at SMKN 2 Mojokerto, has provided standards regarding cookies that are acceptable in the market, ranging from taste, shape, and type, to the production process that is acceptable. effective and efficient. However, Midas Cookies did not provide space for teachers of SMKN 2 Mojokerto to have the opportunity to do internships and add experience to the pastry making program and did not provide support in terms of the equipment used for the pastry production process. This is one of the things that has not been optimal in the implementation of the teaching factory at SMKN 2 Mojokerto, because the teacher who accompanies students in the pastry production activity program has less experience regarding the production of pastries. So far, the implementation of the teaching factory program that has been carried out at SMKN 2 Mojokerto tends to provide expertise to the students of the Catering Service program in producing pastries. The measure of the success of students in implementing the pastries program so far is based on the ability to be able to sell pastries products in accordance with predetermined targets. However, there is no assessment measure regarding each production process carried out by students during the teaching factory implementation. So that the measure of the achievement of competence of each student in carrying out the pastry activity program is not clearly measurable. On the other hand, competence is an important matter, because without having good competence, students will find it difficult to survive and adapt in the world of work or the business world and the industrial world which is marked by the work readiness of students who are not good. If there is no clear measurement in the implementation of the teaching factory, then the assessment of increasing student competence becomes less clear and the impact is immeasurable, students will experience doubts about their competence or expertise so that feelings of anxiety arise about readiness to working.

Based on this explanation, this study was conducted with the aim of analyzing the effect of implementing the teaching factory on the competence and readiness to working of students. This study also aims to explain the effect of implementing the teaching factory on readiness to working through the competence of students at SMKN 2 Mojokerto. 


\section{Literature Review}

\subsection{Teaching Factory}

Teaching factory is learning that uses concepts to approach the industrial environment in real terms, namely applying the principle of cooperation with industry or learning based on products so that graduates have certain competencies and skills (Fitrihana, 2017). Teaching factory can explain is the difference between the teaching factory and other education in vocational schools is the actual concept of learning, which serves to bridge the competency gap that exists in the industrial world and school knowledge. (Gozali, Dardiri, \& Soekopitojo, 2018). This definition can be understood that the main principle in the teaching factory is to introduce and provide students with the best possible experience about products and work in the industrial business. With the hope that students can prepare themselves in the industrial business. Teaching factory can also be explained as a conceptual approach that combines learning and work environments from realistic and relevant learning experiences (Sutinah, 2020). Teaching factory is able to train students to achieve certain punctuality and quality required by industry, as well as prepare certain skill competencies and shape and instill the mentality of students to be able to adapt and compete in the industrial business (Handayani, Mundilarno, \& Mariah, 2018). Therefore, the teaching factory is a comprehensive learning, integrated between learning and entrepreneurship and its implementation is expected to be able to form students who are competent and have the best possible skills. (Kurniawan, 2017).

Based on this definition, teaching factory can be explained as learning that introduces various forms of problems that exist in the world of work or the business world and the industrial world to students. Through the teaching factory, every aspect of the work process is introduced so that students can recognize every competency needed in the world of work and can form better readiness to working. Teaching factory is a learning model that can encourage students to reach the competent stage, where students have the appropriateness to be given responsibility because they are considered to have the ability. The implementation of the teaching factory involves three elements, namely: (1) students who act as workers; (2) teachers as assessors, consultants, facilitators, and the person in charge of the entire learning program; and (3) the giver or owner of the order either from the individual side or the school itself (Wijoyo, 2021). The implementation of the teaching factory in a school environment has several series with flow of activities, including: (1) receiving orders from the order giver; (2) analyzing orders; (3) declare readiness to work on orders; (4) working on orders; (5) perform quality control; (6) submit the order (Wijoyo, 2021).

\subsection{Competence}

Hooghiemstra (1992) explained that competence is a motive, trait, self-concept, attitude, knowledge, or cognitive skill of each individual that can be measured or calculated reliably. According to Parry (1996), competence is a collection of knowledge, attitudes, and related skills that affect most of a person's roles or responsibilities, which are correlated with the world of work, and can be measured by clear standards, and can be improved through training and development. Spencer, Jr. \& Spencer (1993) explained that competence is an individual characteristic that has three levels: (1) knowledge and skills as basic level competencies, so they must be clearly observed and measured; (2) traits and motives that exist within a person and have a tendency for individual characteristics that are similar to personality; (3) Self-concept has a scope of attitudes, values held, and the image of a person. The three levels of competence described by relate to Spencer, Jr. \& Spencer (1993) relates to one's ability or readiness to working. Widihastuti (2007) also explains that competence is knowledge, skills, and abilities that are mastered by a person and have become part of him, where this competence is then demonstrated through good cognitive, affective, and psychomotor behavior. Letina (2020) explains competence as a process of finding learning itself that allows students to learn more effectively.

Based on the various understandings that have been explained, competence can be explained as a combination of knowledge, skills, and good attitudes to then shape a person to be able to carry out an activity well. Letina (2020) explains that competence is the core of the educational process. This is because competence can affect the ability to manage students' professional careers in the future, therefore competence development is an important matter for students. Without having good competence, a student when entering the world of work will be faced with an increased risk of social and economic exclusion. Bloom's taxonomy explains that there are three aspects that make up competence, namely: cognitive aspects, psychomotor aspects, and affective aspects. Hoque (2016) explains the cognitive aspect explaining the thinking ability of students. Further explained, cognitive aspects include the ability to process information, build an understanding, apply knowledge, solve a problem, and conduct research. The psychomotor aspect describes a person's abilities related to physical function and interpretive movements. Aziz, Nurjanah, \& Sari (2017) explain the psychomotor aspect of explaining the skills of students. The skill in question is the ability of students to be able to understand every knowledge gained comprehensively by students so that they can 
implement every knowledge they have. The affective aspect is explained as a person's ability to be able to control feelings, emotions and attitudes during an activity (Hoque, 2016). Aziz et al. (2017) added that in Indonesia, the affective aspect is one aspect that generally students are weak in mastering these abilities. Therefore, in learning activities in schools, including in the implementation of teaching factories in the affective aspects of students, they are also formed and built so that they can affect attitudes to be able to carry out work activities well when entering the industry business.

\subsection{Readiness To Work}

Readiness to work is a benchmark for graduates having attitudes and skills that lead to being ready to work and succeed in the industry business (Caballero, Walker, \& Fuller-Tyszkiewicz, 2011). Readiness to work can also be explained as the level of a person's ability and willingness to complete a task (Hersey \& Blanchard, 1996). Readiness to work is the first qualification for graduates who are looking for work. Graduates need to have practical and academic readiness in carrying out work duties and responsibilities, so that they can support work performance and the success of the profession being carried out (Sagita, Hami, \& Hinduan, 2020). Makki, Javaid, \& Bano (2016) describe readiness to work as skills, knowledge, and attitudes that enable new graduates to be able to make a positive contribution in the workplace. Purnawan, Santosa, \& Kurniawan (2020) explain that readiness to work is a person's ability to be able to complete a job in accordance with the provisions without experiencing obstacles with maximum results in accordance with predetermined targets.

Based on this understanding, readiness to work can be explained by the work abilities that have been possessed by students who have graduated from vocational high schools in accordance with predetermined standards so that they can quickly adapt to the work environment. A vocational student who has good readiness to work can be demonstrated through good abilities, skills, attitudes, and personalities in carrying out activities. It is hoped that every vocational high schools graduate has good readiness to work so that they can compete in the industrial business. Readiness to work itself describes the type of ability of students which includes aspects of understanding, aspects of knowledge, aspects of skills, and aspects of personality (Alimudin, Permana, \& Sriyono, 2019).

Understanding describes a person's ability to be able to understand any material that has been delivered or given and can use the material without the need to relate it to other matters. Knowledge describes a person's ability to be able to remember, recognize and recall about a concept, fact, or material that has been explained and given during the learning process. Skills describe a person's ability to be able to apply any material that has been delivered or given during learning. Skills can also be explained as the ability to be able to apply any results from the knowledge and understanding of a person or student that has been previously possessed. Personality describes a person's ability to be able to bring out the potential that exists within oneself. This can be realized through work ethics, responsibility, passion for business, time management skills, communication skills, and collaboration (Muspawi \& Lestari, 2020).

\section{Materials and Methods}

The study conducted is ex-post facto research, which explains phenomena where the consequence is to determine the subject or variable that can lead to consequences (Sukardi, 2021). The phenomenon in question is to explain the effect of implementing the teaching factory on readiness to work through competence. The variables studied consisted of three types. The independent variable is the implementation of the teaching factory $(\mathrm{X})$, the dependent variable is readiness to work (Y2), and the intervening variable is competence (Y1). This study uses a target population in the form of all vocational high school students in East Java Province who carry out teaching factory. The affordable population used were students of class XI and XII of the catering service program at SMKN 2 Mojokerto with a total of 6 classes with a total of 193 students. Class XI and class XII were chosen as the research population, because they were students of the Catering Service program who had experienced and implemented the pastry making program which was a form of implementing the teaching factory at SMKN 2 Mojokerto. Based on the number of affordable population, the determination of the research sample using the Slovin formula and it is known that the number of research samples is 130 students of class XI and class XII of SMKN 2 Mojokerto Catering Service Program. The sampling process is carried out by simple random sampling, which is a sampling technique that is carried out simply and randomly without regard to the levels contained in the population. The research sample was taken by simple random sampling assuming the affordable population of this study was a homogeneous population. Collecting research data using a questionnaire for the variable implementation of teaching factory and readiness to work, while for the competency variable using tests for cognitive aspects, and observation sheets for psychomotor and affective aspects. The data that has been collected is then analyzed using path analysis and Sobel test. The analytical tool used is SPSS 22. 


\section{Results and Discussions}

Based on the research objectives, it is known that this study tested four hypotheses, namely: (1) the implementation of the teaching factory had a positive effect on competence; (2) the implementation of the teaching factory has a positive effect on readiness to work; (3) competence has a positive effect on readiness to work; and (4) the implementation of the teaching factory affects readiness to work through competence. The four hypotheses proposed form two regression models and are analyzed using path analysis and Sobel test. Prior to conducting path analysis, both regression models were tested with prerequisites, which consisted of the assumption of normality, the assumption of heteroscedasticity, the assumption of multicollinearity, and the assumption of autocorrelation. The results of the prerequisite test indicate that both models have met every assumption, so that both regression models can be used to test the research hypothesis. The results of the regression analysis for the first regression model show in Table 1.

Table 1. Regression Equation Results for Regression Model 1

\begin{tabular}{ccccc}
\hline Model & Regression Coefficient & t-stat & Sig. & Explanation \\
\hline (Constant) & 1,144 & 8,539 & 0,000 & \\
Implementation Of The Teaching Factory & 0,313 & 8,445 & 0,000 & Positive effect \\
\hline
\end{tabular}

Source: (results of analysis conducted by researchers, 2021)

Based on the results in Table 1, the regression equation for the first model can be realized as follows.

Y1 $=1,144+0,313 \mathrm{X}$

Explanation:

$\mathrm{Y} 1=$ Competence

$\mathrm{X}=$ Implementation of The Teaching Factory

The results in Table 1 show that the implementation of the teaching factory has a positive effect on competence. These results prove that the first hypothesis proposed in this study is accepted. The results of this study explain that when students of the Catering Service Program can carry out the teaching factory well, their competencies will increase and become better. On the other hand, if students cannot carry out the teaching factory properly, their competence will actually decrease.

The results of this study support the results of research conducted by Siswanto (2011), that the implementation of the teaching factory can be more effective in supporting the improvement of student competence if it is supported by various parties, such as support from the industry. The results of the study also support the research conducted by Sugiarti, Maryati, \& Azizah (2018) in class XII students of the Agricultural Product Processing Technology Program at SMKN 1 Kuningan. The results of the research by Sugiarti, Maryati, \& Azizah (2018) explain that the implementation of the teaching factory can be a suggestion to train students' abilities and skills, so that students' competencies increase and become better. The value of the correlation coefficient and the coefficient of determination for the first regression model is shown in Table 2.

Table 2. Value of Correlation Coefficient and Coefficient of Determination of Regression Model 1

\begin{tabular}{cccc}
\hline $\mathbf{R}$ & R Square & Adjusted R Square & Std. Error od The Estimate \\
\hline 0,598 & 0,358 & 0,353 & 0,1265422 \\
\hline
\end{tabular}

Source: (results of analysis conducted by researchers, 2021).

Based on the results in Table 2, it is known that the correlation coefficient of model 1 is 0.598 . This value explains the magnitude of the ability to implement the teaching factory to explain the competence of $59.8 \%$. These results explain that the implementation of the teaching factory has a big enough role to improve the competence of the Catering Service Program students at SMKN 2 Mojokerto. In line with the statement expressed by Muslim (2019) that the implementation of the teaching factory in the vocational high school environment aims to provide more opportunities for students to be able to practice every skill they have, so that student competencies can be further honed and increased. Therefore, it is important for every student of the Catering Service Program at SMKN 2 Mojokerto to be able to follow each teaching factory implementation process properly, so that their competence can be increased, both from the cognitive, psychomotor, and affective aspects. The results of the second and third hypothesis testing using the second regression model shown in Table 3.

Table 3. Regression Equation Results for Regression Model 2

\begin{tabular}{ccccc}
\hline Model & Regression Coefficient & t-stat & Sig. & Explanation \\
\hline (Constant) & 1,254 & 4,568 & 0,000 & \\
Implementation Of The Teaching Factory & 0,179 & 2,364 & 0,020 & Positive effect \\
Competence & 0,763 & 5,277 & 0,000 & Positive effect \\
\hline
\end{tabular}

Source: (results of analysis conducted by researchers, 2021) 
Based on the results in Table 3, the regression equation for the first model can be realized as follows.

$\mathrm{Y} 2=1,254+0,179 \mathrm{X}+0,763 \mathrm{Y} 1$

Explanation:

$\mathrm{Y} 2=$ Readiness to work

Y1 = Competence

$\mathrm{X} \quad=$ Implementation of The Teaching Factory

The results in Table 3 explain that the implementation of the teaching factory has a positive effect on readiness to work. These results prove that the second hypothesis proposed in this study is accepted. The results of this study explain that when the implementation of the internal teaching factory is carried out well by the students of the Catering Service Program, then each participant will increasingly feel greater readiness to work. On the other hand, if the implementation of the teaching factory cannot be carried out properly, students will feel unprepared to be able to compete in the work environment. The results of this study support the results of Putri, Isnandar, \& Handayani (2017), which explains that there is a real difference between students who have experienced teaching factory learning and students who have not felt on the work readiness side. Students who have carried out teaching factory can find out the actual working atmosphere, students can also know the work pressure in producing a product or service in an industry. Therefore, the readiness to work of students who have carried out the teaching factory well will be better prepared. The results of this study also support the results of research by Zutiasari, Rahayu, Martha, \& Zumroh (2021), that through the implementation of the teaching factory technical knowledge, group skills, and experience are increasing so that students can become more prepared to face the world of work in an industry.

Table 3 also shows that competence has a positive effect on readiness to work. These results prove that the third hypothesis proposed in this study is accepted. The results of this study explain that when students have better competencies, students can be more confident with their competencies and have better readiness to work. Conversely, if students do not have good competencies, then students become doubtful about the competencies they have, the impact is that students feel increasingly less ready to be able to compete in the work environment. The results of the study support the results of research from Eliyani, Yanto, \& Sunarto (2016), that students who have higher competencies obtained during the learning process can increase their confidence in facing competition in the industrial business. The results of research from Pangastuti \& Khafid (2019) also explain that students who have good competence tend to have good abilities from the side of finding ideas to job information and various alternatives that can support careers, so that students' readiness to work is better.

Table 4. Significance Results of Multiple Regression Model 2

\begin{tabular}{cccccc}
\hline Model & Sum of Squares & df & Mean Squares & F-stat & Sig. \\
\hline Regression & 3,227 & 2 & 1,614 & 37,643 & 0,000 \\
Residual & 5,444 & 127 & 0,043 & & \\
Total & 8,671 & 129 & & & \\
\hline
\end{tabular}

Source: (results of analysis conducted by researchers, 2021)

The results in Table 4 show the significance value shown at $0.000<0.05$. This value explains that all the independent variables used, namely the implementation of teaching factory and competence simultaneously have a significant effect on readiness to work.

Table 5. Value of Correlation Coefficient and Coefficient of Determination of Regression Model 2

\begin{tabular}{cccc}
\hline $\mathbf{R}$ & R Square & Adjusted R Square & Std. Error od The Estimate \\
\hline 0,610 & 0,372 & 0,362 & 0,2070382 \\
\hline
\end{tabular}

Source: (results of analysis conducted by researchers, 2021)

The results in Table 5 show the coefficient of determination of 0.372 . This value explains the ability to implement the teaching factory and the competence to explain readiness to work by $37.2 \%$.

In the indirect effect test using the path equation model which is described as follows. 




Figure 1. Equation Path Analysis Model of Implementation of The Teaching Factory (X) on Readiness to Work (Y2) through Competence (Y1)

Figure 1 shows the value of the regression coefficient $(\beta 1)$ the effect of implementing of the teaching factory on competence is 0.313 , the value of the regression coefficient $(\beta 2)$ is the effect of implementing the teaching factory on readiness to work of 0.179 , and the regression coefficient $(\beta 3)$ the effect of competence on readiness to work is 0.763 . Based on the value of the regression coefficient, it can be calculated that the regression coefficient value of the indirect effect of the implementation of the teaching factory on readiness to work through competence is 0.239 which is obtained by multiplying $\beta 1$ with $\beta 3$. The value of the regression coefficient of the indirect effect is greater than the value of the regression coefficient of the direct influence of the implementation of the teaching factory on readiness to work which is 0.179 . These results explain that the implementation of the teaching factory affects readiness to work through competence. This is evidenced by the results of the Sobel test.

\begin{tabular}{|c|c|c|c|c|c|}
\hline & Input: & & Test statistic: & Std. Error: & $p$-value: \\
\hline$a$ & 0.313 & Sobel test: & 4.46817218 & 0.05344893 & 0.00000789 \\
\hline$b$ & 0.763 & Aroian test: & 4.44583159 & 0.05371751 & 0.00000876 \\
\hline$s_{a}$ & 0.037 & Goodman test: & 4.49085299 & 0.05317898 & 0.00000709 \\
\hline$s_{b}$ & 0.145 & Reset all & \multicolumn{3}{|c|}{ Calculate } \\
\hline
\end{tabular}

Figure 2. The results of the Sobel Indirect Influence Test using http://quantpsy.org/sobel/sobel.htm

The significance value of the results of the Sobel test in Figure 2 is $0.00<0.05$ (critical value $5 \%$ ). These results explain that there is an indirect effect of the implementation of the teaching factory on readiness to work through competence. These results prove that the fourth hypothesis proposed in this study is acceptable. These results explain that students who can carry out the teaching factory well that has been provided at SMKN 2 Mojokerto can improve the competence of students for the better so that every student has readiness to work who also becomes more prepared. On the other hand, if students cannot follow the implementation of the teaching factory properly, the competence of students will not increase and participants will have doubts about their readinessto work.

The results of this study support the research results of Putri et al. (2017) which explains that vocational education has a function to prepare students to work in certain areas of expertise according to their competencies. Zutiasari et al. (2021) added that the implementation of the teaching factory contributed to improving the competence of vocational students. Vocational high school students who experienced an increase in this competency tended to show better readiness to work than students who did not show an increase in competence. According to Parry (1996), competence is an important matter to be able to improve students' readiness to work when the implementation of teaching factory in SMK is carried out well. Therefore, the implementation of a teaching factory in a vocational high school can be said to be effective if it can improve student competence and lead to the formation of better student readiness to work.

\section{Conclusions}

Based on the results of the research and discussion that have been explained, the conclusions of this study are: (1) The implementation of the teaching factory has a positive effect on the competence of the students of the Catering Service Program at SMKN 2 Mojokerto; (2) The implementation of the teaching factory has a positive effect on the readiness to work of the Catering Service Program students at SMKN 2 Mojokerto; (3) 
The competence of students has a positive effect on the readiness to work of students in the Catering Service Program at SMKN 2 Mojokerto; and (4) the implementation of the teaching factory has a positive effect on the readiness to work of the Catering Service Program students at SMKN 2 Mojokerto through the competence of students. Based on the conclusions of the study, the suggestions that can be put forward through this research are that students should be able to seriously and concentrate in carrying out each teaching factory process provided by the vocational high school, so that students benefit by increasing competence and better readiness to work. In addition, teachers who support the implementation of the teaching factory should be able to give better attention during the preparation of the teaching factory implementation program, such as providing a variety of programs that can improve the competence of students in accordance with the objectives of the Catering Service Program at SMKN 2 Mojokerto. The implications of this research are: (1) The effect of the implementation of the teaching factory on the competence of students is $59.8 \%$, therefore schools need to be able to support the implementation of the teaching factory better; and (2) The effect of the implementation of teaching factory and competence on readiness to work is $37.2 \%$, therefore schools need to develop a teaching factory implementation program that can support the improvement of competencies that are attractive to students, so that students can improve their readiness to work for the better.

\section{Acknowledgement}

The authors would like to thanks the supervisors from Magister of Vocational Education, State University of Surabaya for their assistance in the completed this study.

\section{Author's Contributions}

All authors discussed the results and contributed to from the start to final manuscript.

\section{Conflict of Interest}

The authors declare that they have no competing interests.

\section{References}

Alimudin, I. A., Permana, T., \& Sriyono, S. (2019). Studi Kesiapan Kerja Peserta Didik Smk Untuk Bekerja Di Industri Perbaikan Bodi Otomotif. Journal of Mechanical Engineering Education, 5(2), 191. https://doi.org/10.17509/jmee.v5i2.15187

Asriati, N., Sulistyarini, Ulfah, M., \& Purwaningsih, E. (2017). Pengembangan Model Pembelajaran Teaching Factory 6M Menghadapi Revolusi Industri Keempat Di SMK Negeri 6 Pontianak. Jurnal Pendidikan Ekonomi, 3(2), 1-18.

Aziz, F., Nurjanah, F., \& Sari, D. P. (2017). Aktualisasi TTB (Teori Taksonomi Bloom) Melalui Drama Kepahlawanan Guna Penanaman Pendidikan Karakter Pada Peserta Didik. FKIP E-Proceeding PBSI Universitas Jember, 715-724.

Caballero, C. L., Walker, A., \& Fuller-Tyszkiewicz, M. (2011). The Work Readiness Scale (WRS): Developing a measure to assess work readiness in college graduates. Journal of Teaching and Learning for Graduate Employability, 2(1), 41-54. https:/ / doi.org/10.21153/jtlge2011vol2no1art552

Cahyani, D. R. (2019). Daya Saing Global Turun, Sri Mulyani: Karena Kualitas SDM Rendah. Retrieved July 1, 2021, from Tempo website: https://bisnis.tempo.co/read/1258628/daya-saing-global-turun-sri-mulyani-karena-kualitassdm-rendah

Daulay, H. (2019). Pendidikan Islam di Indonesia Historis dan Eksistensinya. Yogyakarta: Kencana.

Eliyani, C., Yanto, H., \& Sunarto. (2016). Determinan Kesiapan Kerja Siswa SMK Kelas XII Kompetensi Keahlian Akuntansi Di Kota Semarang. Journal of Economic Education, 5(1), 22-30.

Fitrihana. (2017). Model Bisnis Kanvas Untuk Mengembangkan Teaching Factory Di Smk Tata Busana Guna Business Model Canvas To Developing Teaching Factory in Fashion Design Vocational High School. Jurnal Taman Vokasi, $5(2), 212-218$.

Gozali, G., Dardiri, A., \& Soekopitojo, S. (2018). Penerapan Teaching Factory Jasa Boga untuk Meningkatkan Kompetensi Entrepreneur Siswa Sekolah Menengah Kejuruan. JSHP ( Jurnal Sosial Humaniora Dan Pendidikan), $2(1), 46$. https://doi.org/10.32487/jshp.v2i1.264

Handayani, K. S., Mundilarno, M., \& Mariah, S. (2018). Implementasi Manajemen Teaching Factory Di Prodi Kriya Kulit SMKN 1 Kalasan. Media Manajemen Pendidikan, 1(1), 122. https:/ / doi.org/10.30738/mmp.v1i1.2880

Hersey, P., \& Blanchard, K. (1996). Great ideas revisited: Revisiting the life-cycle theory of leadership. Training $\mathcal{E}$ Development, 50(1), 42-47. 
Hooghiemstra, T. (1992). Integrated management of human resources. Competency Based Human Resource Management, 17-46.

Hoque, M. E. (2016). Three Domains of Learning: Cognitive, Affective and Psychomotor. The Journal of EFL Education and Research, 2(February), 2520-5897. Retrieved from www.edrc-jefler.org

Kurniawan, R. (2017). Pengaruh Penerapan Model Pembelajaran Teaching Factory 6 Langkah (Tf-6M) Dan Prestasi Belajar Kewirausahaan Terhadap Minat Wirausaha. Innovation of Vocational Technology Education, 10(1), 57-66. https:// doi.org/10.17509/invotec.v10i1.5092

Letina, A. (2020). Development of students' learning to learn competence in primary science. Education Sciences, 10(11), 114. https://doi.org/10.3390/educsci10110325

Makki, B. I., Javaid, M. U., \& Bano, S. (2016). Level of Work Readiness Skills, Career Self-Efficacy and Career Exploration of Engineering Students. NFC-IEFR Journal of Engineering and Scientific Research, 4(1), 91-96. https://doi.org/10.24081/nijesr.2016.1.0017

Muslim, S. (2019). the Implementation Teaching Factory and Implications on the Preparation of Candidates for Vocational High School Teachers. Humanities $\mathcal{E}$ Social Sciences Reviews, 7(3), 323-330. https://doi.org/10.18510/hssr.2019.7348

Muspawi, M., \& Lestari, A. (2020). Membangun Kesiapan Kerja Calon Tenaga Kerja. Jurnal Literasiologi, 4(1), 111-117. https://doi.org/10.1134/s0514749219040037

Pangastuti, U., \& Khafid, M. (2019). Peran Kematangan Karir dalam Memediasi Kompetensi Kejuruan dan Efikasi Diri terhadap Kesiapan Kerja Siswa. Economic Education Analysis Journal, 8(2), $485-500$. https://doi.org/10.15294/eeaj.v8i2.31496

Parry, S. B. (1996). Just What Is a Competency?(And Why Should You Care?). Training, 35(6), 58.

Purnawan, P., Santosa, B., \& Kurniawan, A. (2020). Automotive Vocational High School: How Career Guidance and Parents Support Impact the Students' Work Readiness. Journal of Vocational Education Studies, $3(1), 61$. https://doi.org/10.12928/joves.v3i1.2142

Putri, D. M., Isnandar, \& Handayani, A. N. (2017). Overview Pelaksanaan Teaching Factory Terhadap Kesiapan Kerja Siswa SMK Memasuki Dunia Industri. In Seminar Nasional Sistem Informasi.

Ramli, R. R. (2020). Jumlah Pengangguran Terus Bertambah, Paling Banyak Lulusan SMK.

Sagita, M. P., Hami, A. El, \& Hinduan, Z. R. (2020). Development of Indonesian Work Readiness Scale on Fresh Graduate in Indonesia. Jurnal Psikologi, 19(3), 297-314. https://doi.org/10.14710/jp.19.3.297-314

Said, U. (2019). Inovasi Kebijakan Pendidikan Kejuruan Berbasis Entrepreneur. Sidoarjo: Zifatama Jawara.

Siswanto, I. (2011). Pelaksanaan Teaching Factory untuk Meningkatkan Kompetensi dan Jiwa Kewirausahaan Siswa Sekolah Menengah Kejuruan. In Seminar Nasional 2011 “Wonderfull Indonesia.”

Spencer, Jr., L. M., \& Spencer, S. M. (1993). Competency at work: Model for superior performance. New Jersey: John Wiley \& Sons.

Sugiarti, Y., Maryati, M., \& Azizah, D. N. (2018). Pengaruh Pelaksanaan Teaching Factory Terhadap Uji Kompetensi Praktik Siswa SMKN 1 Kuningan. Edufortech, 3(2), 85-92.

Sukardi, H. M. (2021). Metodologi Penelitian Pendidikan: Kompetensi dan Praktiknya. Jakarta: Bumi Aksara.

Sutinah, C. (2020). Pengembangan Karakter Kebangsaan dan Karakter Wirausaha Melalui Implementasi Model Pembelajaran Teaching Factory 6 Langkah (TF-6M). Pasuruan: Qiara Media.

Widiatna, A. D. (2019). Teaching Factory: Arah Baru Manajemen Sekolah Menengah Kejuruan di Indonesia. Jakarta: Pustaka Kaji.

Widihastuti. (2007). Pencapaian Standar Kompetensi Siswa SMK Negeri Program Keahlian Tata Busana Di Kota Yogyakarta Dalam Pembelajaran Dengan KBK. Jurnal Penelitian Dan Evaluasi Pendidikan, 10(2), 268-278.

Wijoyo, H. (2021). Edupreneurship. Solok: CV Insan Cendekia Mandiri.

Zutiasari, I., Rahayu, W. P., Martha, J. A., \& Zumroh, S. (2021). Integrasi Pendidikan Bisnis dengan Teaching Factory dan Pengaruhnya Terhadap kesiapan Bekerja Siswa SMK. Jurnal Inovasi Pendidikan Ekonomi, 11(1), 21-32. 